\title{
What is the impact of COVID-19 disease on agriculture?
}

\author{
Raúl Siche $\mathbb{D}$ \\ Facultad de Ciencias Agropecuarias, Universidad Nacional de Trujillo. Av. Juan Pablo II s/n. Ciudad Universitaria, \\ Trujillo, Peru.
}

Received March 30, 2020. Accepted March 31, 2020.

\begin{abstract}
The different pandemics that humanity has experienced, such as the Spanish Flu, Asian Flu, Hong Kong Flu, HIVIAIDS, SARS, Ebola, and Swine Flu, have had a great impact on the economy, the environment and any human activity, such as livestock, agriculture, tourism, transport, education, health, fishing, mining, industry, commerce, etc. Currently, humanity is facing another pandemic, the infection of the new coronavirus (2019-nCoV) that generates the disease known as COVID-19. The objective of this document is to analyze and discuss the effects in agriculture of events related to the disease of COVID19. For this analysis, data from the Food Agriculture Organization (FAO), the World Health Organization (WHO) and scientific and technical documents have been used. There is sufficient evidence to affirm that the pandemic caused by the COVID-19 disease has an important effect on agriculture and the food supply chain, mainly affecting food demand and consequently food security, with a great impact on the most vulnerable population.
\end{abstract}

Keywords: 2019-nCoV; COVID-19; coronavirus; food security; food supply chain; agriculture.

\section{Introduction}

In Wuhan, China, on December 31, 2019, the first cases of infection of a new coronavirus (2019-nCoV) are reported (WHO, 2020a), which generates the disease that is now known as COVID-19 (Wang, 2020), different from SARS-CoV and MERS-CoV. Since that time, the report of globally confirmed cases of infection with this new virus has had an alarming growth (Figure 1), now being the main global health problem, which is affecting the normal development of society and all its components.

There is always a risk of developing a new infectious disease (Burnet and White, 1972), from the Spanish flu of 1918, to AIDS that still has no definitive cure (Table 1). Well now, Covid-19 is the contagious disease that threatens and disturbs humanity.

From past pandemics that the world has experienced, it has been shown that quarantines and panic have an impact on human activities and economic growth (Hanashima and Tomobe, 2012; Bermejo, 2004; Arndt and Lewis, 2001); but, the effect also occurs in agricultural activities. When there is an outbreak of infectious disease, there is also an increase in hunger and malnutrition (Burgui, 2020; Sar et al., 2010).

The situation worsens as the disease progresses, making movement restrictions more and more stringent, causing labor shortages for the harvest, or difficulties for farmers to bring their products to market. Agriculture is one of the most important sectors in human development and is related to food security (Abdelhedi and Zouari, 2020; Kogo et al., 2020; LopezRidaura et al., 2019); hence, the objective of this research is to analyze the relationships between agriculture and food security and how these relationships are being affected by events related to the disease of COVID19. 
Table 1

Main pandemics from the 20th century

\begin{tabular}{lllll}
\hline Name & Time period & Type & Death toll & Reference \\
\hline Spanish Flu & $1918-1919$ & H1N1 & More than 50M & Farmer (2019) \\
Asian Flu & $1957-1958$ & H2N2 virus & $1.15 \mathrm{M}$ & Du et al. (2009) \\
Hong Kong Flu & $1968-1970$ & H3N2 virus & 700,000 and 1M & Wang-Shick (2017) \\
HIVIAIDS & $1981-$ present & Virus & $32 M($ estimate, March 2020) & WHO (2020b) \\
COVID-19 & 2019-Present & Coronavirus & $36,405(31$ March 2020) & WHO (2020c) \\
\hline
\end{tabular}

M: Million.

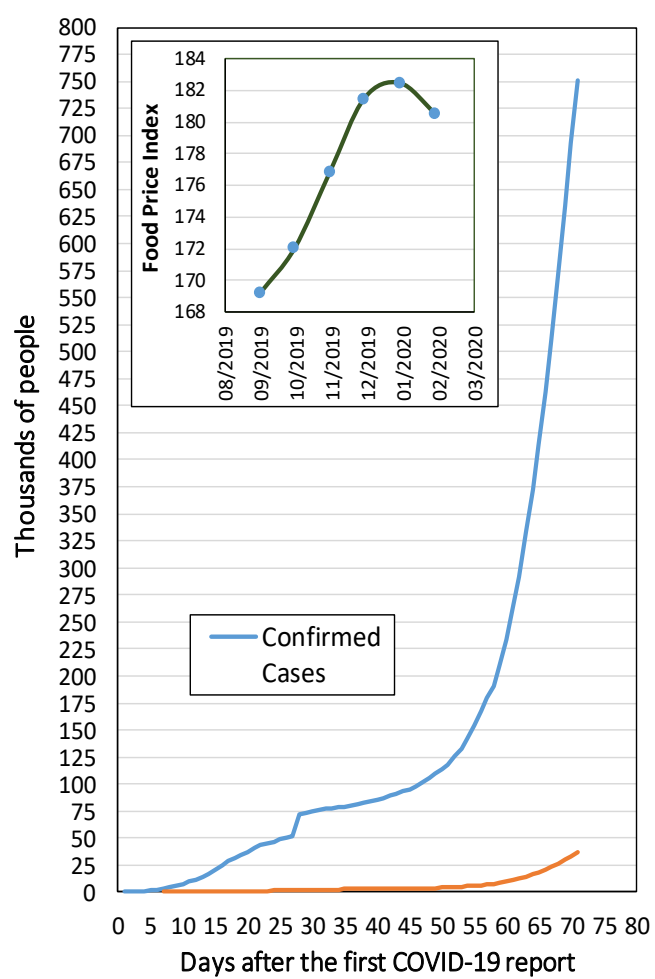

Figure 1. Globally confirmed cases, deaths and Food Price Index by the effect of COVID-19. Graph constructed with data from WHO (2020c), for cases and deaths (updated to March 31, 2020, day 71), and FAO (2020c) for Food Price Index.

\section{Impact of COVID-19 on agriculture}

The Food and Agriculture Organization (FAO, 2020a) states that COVID-2019 is affecting agriculture in two significant aspects: the supply and demand for food. These two aspects are directly related to food security, so food security is also at risk. With Figure 2 you can understand the relationships between these elements, as well as the impact of COVID-19.

\subsection{Food supply}

The food supply chain is a network that connects an agricultural system (the farm) with the consumer's table, including processes such as manufacturing, packaging, distribution, and storage (Chen et al., 2020). Initially, the announcements of social isolation made people go to the supply centers and generate a shortage of some products, despite this, the food supply has stabilized because it is one of the systems that must be maintained to ensure food security. One of FAO's roles is to promote that food value chains are not interrupted and continue to operate (FAO, 2020b). Thus, despite the restrictions that governments have imposed on the mobility of labor in agricultural systems, although with some problems, the supply of basic necessities is normally assured. The situation is different when it comes to goods that are imported or exported; due to the closure of borders, international trade was interrupted, although after having defined security protocols to avoid the spread of the virus, trade stabilized. This may be temporary; it depends on what countries are doing to stop the spread of the virus.

Part of the food supply system, are the social programs that some countries, mainly Latin America, have to feed millions of families and children with limited economic resources. This supply system is being served in different ways:

a. Delivery of food rations of basic necessities (for example, Indonesia and Taiwan).

b. Economic allocation equivalent to the cost of food rations of basic necessity (for example, Peru, Japan, and Singapore).

Interruptions to food transfers are minimal, so the food supply remains stable; although observing China's experience in this pandemic, there is a greater impact on the livestock sector due to difficulties in accessing animal feed and, on the other hand, the shortage of labor (Zhang, 2020).

Although it depends on the country and the measures that each one has adopted, globally the prices have remained stable, therefore, no spikes in the prices of basic necessities are expected, although it is more likely to occur for high-value products, especially meat and perishables. One of the indices that measure the variation of the price worldwide is the FAO Food Price Index (FFPI), a measure of the monthly variation of the international prices of a basket of food products. According to the FAO (2020c), the FFPI of February 2020 had an average of 180.5 points, that is, 1.9 points $(1.0 \%)$ less than in January, constituting the first monthon-month decrease after four months consecutive increases (Figure 1). 


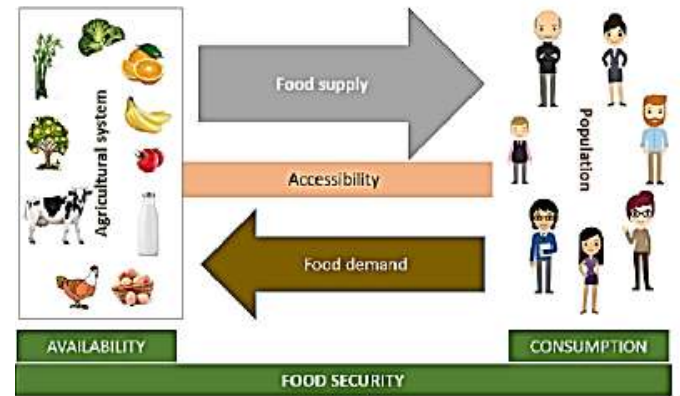

(a)

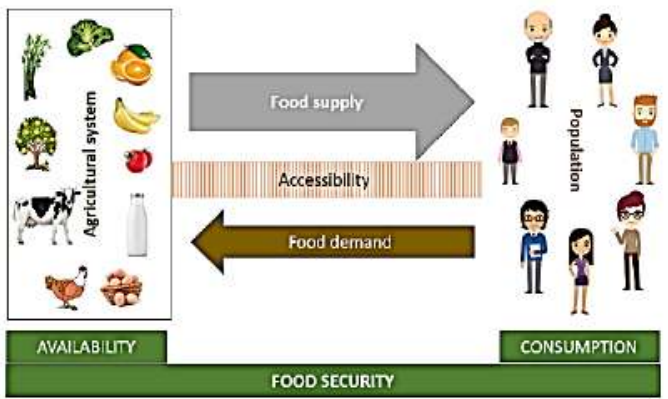

(b)

Figure 2. Food security system (a) without COVID-19 and (b) with COVID-19. Both supply and demand have been affected, although a greater effect on demand, due to the passability restrictions that affect accessibility. Availability and consumption remain almost stable. The agricultural system includes producers, raw materials, agricultural machinery and inputs, processing plants, and farm and industrialized food. Consumption includes people and different marketing systems.

This was due to a sharp fall in the export prices of vegetable oils and, to a lesser extent, in the prices of meat and cereals, which offset the continuing rise in the prices of dairy products and sugar.

\subsection{Food demand}

Demand implies the willingness and ability of consumers to pay money for a particular good or service, during any particular period (Gottheil, 2013).

The demand for food has decreased due to uncertainty and the reduction of people's spending capacity, although this decrease is still slight; the situation could worsen if the pandemic continues for a long time, due to reduced income and job losses (FAO, 2020b).

Since China represents an important market in world trade and where the COVID-19 disease started, his experience shows an increase in online demand in the food and beverage sector, due to quarantine policies (FAO, 2020a). In situations like these, where a virus spreads on contact, contactless delivery services become preferred by consumers. For example, those who use drones for the product delivery (Figure 3).

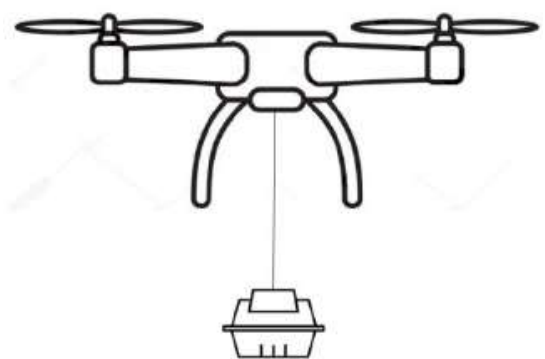

Figure 3. Drone-based system for non-contact food delivery.

\subsection{Food security}

Food security implies that everyone has unrestricted access to food that allows them to satisfy their basic needs (Rosales and Mercado, 2020). Not taking quick action implies an imminent food crisis, with a greater effect on the most vulnerable population (Figure 4). Measures should focus on keeping global food supply chains active and mitigating the impacts of the pandemic across the food system. Social programs act as an umbrella that minimizes the effect of short-term crises.

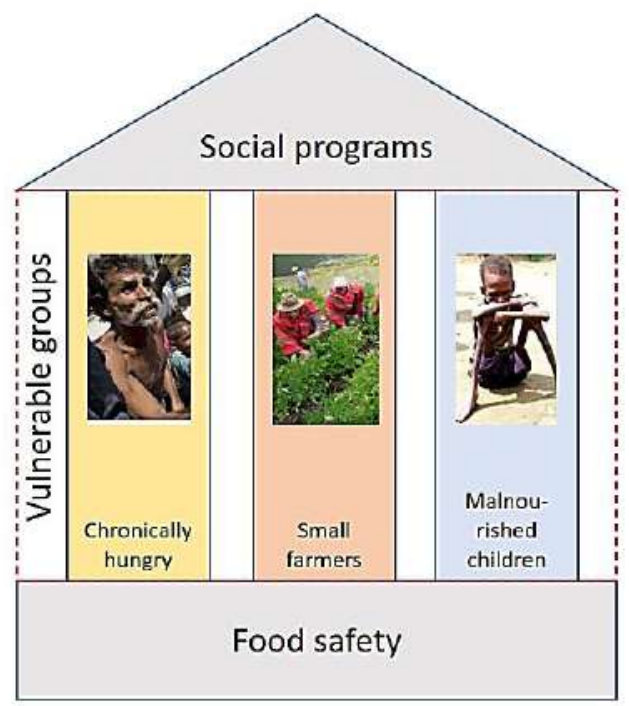

Figure 4. Groups vulnerable to a food crisis.

The first vulnerable group: people who experience chronic hunger and do not consume enough caloric energy to live a normal life, which currently numbers about 820 million people (FAO, 2020a). This group of people cannot afford any possible interruption of their livelihoods or access to food that a situation with COVID-19 could bring. If the virus spreads in countries where such people live, with health systems with limited capacity, the consequences could be serious. 
A second vulnerable group: small farmers, who may be prevented from working on their land and accessing markets to sell their products or buy seeds and other essential inputs.

The third vulnerable group: children from low-income families, who are mainly nourished by food provided by social programs; the suspension of these programs due to the pandemic puts food security and nutrition at risk, and as a consequence the existence of children with limited capacity to cope with diseases (FAO, 2020d). Thus, each country must direct its actions to maintain social food programs, taking the necessary precautions to avoid transmission of the virus.

\section{Conclusions}

The pandemic called COVID-19 disease has a great impact on the actions and activities of humanity, agriculture is not outside this impact. Food demand and thus food security are greatly affected due to mobility restrictions, reduced purchasing power, and with a greater impact on the most vulnerable population groups. As cases of contagion increase, governments take more drastic measures to stop the spread of the virus, also influencing the global food system. The premise of any measure adopted should be to protect the health and food security of the population, to the detriment of economic growth, although some governments go in the opposite direction.

\section{ORCID}

R. Siche (D) https://orcid.org/0000-0003-3500-4928

\section{References}

Abdelhedi, I.T.; Zouari, S.Z. 2020. Agriculture and Food Security in North Africa: a Theoretical and Empirical Approach. Journal of the Knowledge Economy (in press).

Arndt, C.; Lewis, J.D. 2001. The HIVIAIDS pandemic in South Africa: Sectoral impacts and unemployment. Journal of International Development 13(4): 427-449.

Bermejo, A. 2004. HIVIAIDS in Africa: International responses to the pandemic. New Economy 11(3): 164-169.

Burgui, D. 2020. Coronavirus: How action against hunger is responding to the pandemic. Available in: https://www.actionagainsthunger.org/story/coronav irus-how-action-against-hunger-respondingpandemic

Burnet, M.; White, D.O. 1972. Natural history of infectious disease. 4th ed. Cambridge, United Kingdom: Cambridge University Press. 279 pp.

Chen, S.; Brahma, S.; Mackay, J.; Cao, C.; Aliakbarian, B. 2020. The role of smart packaging system in food supply chain. Journal of Food Science 85(3): $517-$ 525

Du, N.; Yang, X.X.; Yang, L.; Zeng, Y.H.; Zou, S.M.; Bo, H.; Guo, Y.J.; Li, D.X.; Shu, Y.L. 2009. Review on the etiological property of 1957 Asian flu virus (H2N2). Chinese Journal of virology 25: 12-16.

FAO - Food and Agriculture Organization. 2020a. Q\&A: COVID-19 pandemic - impact on food and agriculture. Available in: http://www.fao.org/2019ncov/q-and-a/en/

FAO - Food and Agriculture Organization. 2020b. FAO Director-General urges $\mathrm{G} 20$ to ensure that food value chains are not disrupted during COVID-19 pandemic. Available in:

http://www.fao.org/news/story/en/item/1268254/ico del

FAO - Food and Agriculture Organization. 2020c. FAO Food Price Index. Available in:

http://www.fao.org/worldfoodsituation/foodpricesin dex/en/

Farmer, P. 2019. Ebola, the Spanish flu, and the memory of disease. Critical Inquiry 46(1): 56-70.

FAO - Food and Agriculture Organization. 2020d. FAO alerta sobre el impacto del COVID19 en la alimentación escolar de América Latina y el Caribe. Available in:

http://www.fao.org/americas/noticias/ver/es/c/1267 $028 /$

Gottheil, F.M. 2013. Principles of Microeconomics. 7th Edition. Cengage Learning. EEUU. 592 pp.

Hanashima, M.; Tomobe, K. 2012. Urbanization, industrialization, and mortality in modern Japan: A spatiotemporal perspective. Annals of GIS 18(1): 57-70.

Kogo, B.K.; Kumar, L.; Koech, R. 2020. Climate change and variability in Kenya: a review of impacts on agriculture and food security Environment, Development and Sustainability (in press).

Lopez-Ridaura, S.; Barba-Escoto, L.; Reyna, C.; Hellin, J.; Gerard, B.; van Wijk, M. 2019. Food security and agriculture in the Western Highlands of Guatemala. Food Security 11(4): 817-833.

Rosales, G.; Mercado, W. 2020. Efecto de los cambios en el precio de los alimentos sobre el consumo de la quinua y la seguridad alimentaria rural en el Perú. Scientia Agropecuaria 11(1): 83-93.

Sar, T.T.; Aernan, P.T.; Houmsou, R.S. 2010. H1N1 Influenza Epidemic: Public Health Implications for Nigeria. International Journal of Virology 6: 1-6.

Wang-Shick, R. 2017. Molecular Virology of Human Pathogenic Viruses. Elsevier Inc. Academic Press. 440 pp.

Wang, H.; Wang, Z.b.; Dong, Y.; Chang, R.; Xu, C.; Yu, X.; Zhang, S.; Tsamlag, L.; Shang, M.; Huang, J.; Wang, Y.; Xu, G.; Shen, T.; Zhang, X.; Cai, Y. 2020. Phaseadjusted estimation of the number of Coronavirus Disease 2019 cases in Wuhan, China. Cell Discovery 6(1): Article number 10.

WHO - World Health Organization. 2020b. HIVIAIDS: Global situation and trends. Global Health Observatory (GHO) data. Available in: https://www.who.int/gho/hiv/en/

WHO - World Health Organization. 2020c. Coronavirus disease (COVID-2019) situation reports. Available in: https://www.who.int/emergencies/diseases/novelcoronavirus-2019/situation-reports

WHO - World Health Organization. 2020a. Novel Coronavirus (2019-nCoV). Situation Report - 1. 21 January 2020. 5 pp. Available in:

https://www.who.int/emergencies/diseases/novelcoronavirus-2019/situation-reports/

Zhang, X. 2020. Chinese livestock farms struggle under COVID-19 restrictions. Research Post of International Food Policy Research Institute. Available in: https://www.ifpri.org/blog/chinese-livestock-farmsstruggle-under-covid-19-restrictions 